\title{
Cenas tīrelī iegūto radiolokācijas signālu analīze
}

\author{
Jānis Karušs ${ }^{1}$, Valdis Segliṇš ${ }^{2},{ }^{1-2}$ Latvijas Universitāte
}

\begin{abstract}
Kopsavilkums. Pētījums ir veltīts purvu nogulumos iegūto radiolokācijas signālu analīzei un interpretācijai. Tiek sniegts pētījumu teritorijas geolog̣iskās uzbūves apraksts, izmantotās pētijumu metodikas apraksts darbā ar $300 \mathrm{MHz}$ antenu sistēmu, analizēta kūdras sadalī̌̌anās pakāpe, pelnainība un dabiskais mitrums. Tāpat ir sniegta detāla iegūto radiolokācijas signālu analīze. Secināts, ka elektromagnētisko viḷnu izplatīšanās ātrumu kūdrā nenosaka tikai kūdras mitruma daudzuma izmaiņas. Pētījumos ar radiolokācijas metodi elektromagnētisko viḷnu izplatī̌sanās ātrums kūdras slāņos jānosaka ar augstu precizitāti, izmantojot kopējā viduspunkta metodi.
\end{abstract}

Atslēgas vārdi: geooradars, geofizika, Cenas tīrelis, kūdras elektromagnētiskās īpašības.

\section{IEVADS}

Radiolokācijas metode tiek pielietota purvu nogulumu pētījumos salīdzinoši sen, un jau pagājušā gadsimta septiṇdesmito gadu beigās tika pierādīts, ka radiolokācijas metodi ir iespējams pielietot kūdras krājumu novērtēšanā purvos [1]. Signāli tika konstatēti, korelēti ar ǵeoloǵiskā griezuma raksturīgām virsmām un sekmīgi pielietoti kūdras novērtējumam vienkāršiem izmantošanas veidiem. Turpmākajos gados padziļināti pētījumi nesekoja un iemesli, kāpēc radiolokācijas signāla atstarojums ir izveidojies, ir skaidroti salīdzinoši vienkāršoti.

Bieži vien ir ticis pausts viedoklis, ka iegūtie radiolokācijas signāli ir saistîti ar nogulumu mitruma daudzuma izmaināām griezumā [2,3]. Tāpat līdzšinējos pētījumos bieži vien tiek atzīmēts, ka iegūtie radiolokācijas signāli var būt saistīti ar kūdras humifikācijas pakāpes izmain̄ām griezumā [4,5]. Minētais norāda, ka līdz šim nav rasts pietiekami pamatots skaidrojums radiolokācijas signāla atstarojumiem purvu nogulumos.

Neskatoties uz to, ka radiolokācijas metode tiek attīstīta jau vairākus gadu desmitus, joprojām nav izstrādāta lauka darbu standartizēta metodika, kā arī datu apstrādes procedūras un metodika - tās vienmēr ir tikušas pielāgotas konkrētā pētījuma vajadzībām [2,5].

N̦emot vērā iepriekšēji minēto, pētījuma mērķis ir noskaidrot kūdras fizikālās īpašības, kas galvenokārt nosaka kūdras elektromagnētiskās īpašības, kā arī identificēt atstaroto signālu īpašības un sniegt to ǵeoloǵisko interpretāciju.

\section{PĒTİJUMU TERITORIJA}

Pētījums tika realizēts Cenas tīrelī aptuveni $18 \mathrm{~km}$ uz DR no Rīgas (1. att.). Purva teritorija atrodas Piejūras dabas apvidū, kuram raksturīgs salīdzinoši līdzens reljefs, kas arī ir veicinājis augstā tipa purvu veidošanos. Purva platība ir 8983 ha, un tā lielāko dạı - 6200 ha aizṇem augstā tipa purvs. Cenas tīrelis ir veidojies Baltijas ledus ezera nogulumu virsmas pazeminājumā, pārsedzot smilšainus un mālsmilts nogulumus.

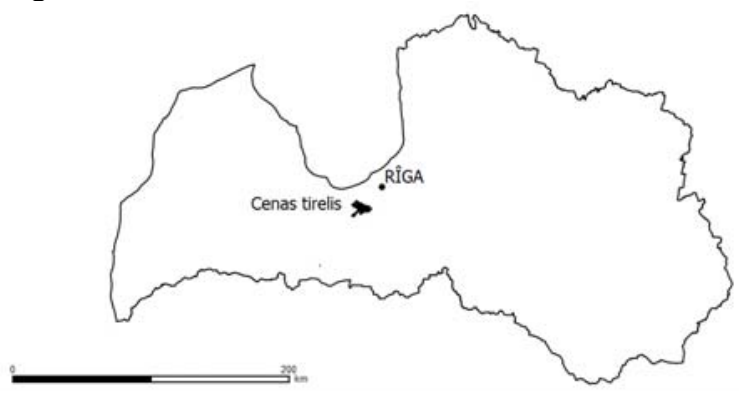

1. att. Pētījumu teritorijas novietojums.

Izmantojot laboratorijas analīžu rezultātus, tika noteikts, ka pētījumu teritorijā purvu nogulumu virsējo kārtu, aptuveni 2,5 m biezumā, veido augstā tipa kūdra. Griezumā izdalāmi fuskuma sfagnu, spilvju sfagnu, magelānsfagnu, šeihcēriju sfagnu un šaurlapu sfagnu kūdras slāņi. Dziḷāk ieguḷ aptuveni 0,1 m biezs pārejas tipa kūdras slānis, kuru veido vairāki zāḷu sfagnu, grīšlu un grīšlı hipnu kūdras slānīši. Purva nogulumu dziḷākos slānus veido apmēram 1,8 m biezs zemā tipa kūdras slānis, kuru veido grīšlı, grīšlu hipnu, zāḷu un koku grīšlu kūdra. Pētījumu teritorijā purva pamatni veido Baltijas ledus ezera smilšaini un aleirītiski nogulumi, šeit to biezums pārsniedz 5 metrus un šajā pētījumā tie netika īpaši analizēti.

\section{MATERIĀLI UN METODES}

Pētījumā tika izmantots SIA Radar Systems Latvijā ražotais divkanālu ǵeoradars Zond-12e. Iepriekšēji veiktie pētījumi norāda $[6,7,8]$, ka labākie rezultāti var tikt iegūti, izmantojot antenu sistēmas ar rezonanses frekvenci, kas tuva $250 \mathrm{MHz}$, tādēl mūsu pētījumā tika izmantota sērijveidā ražotā $300 \mathrm{MHz}$ ekranēta antenu sistēma (2. att.).

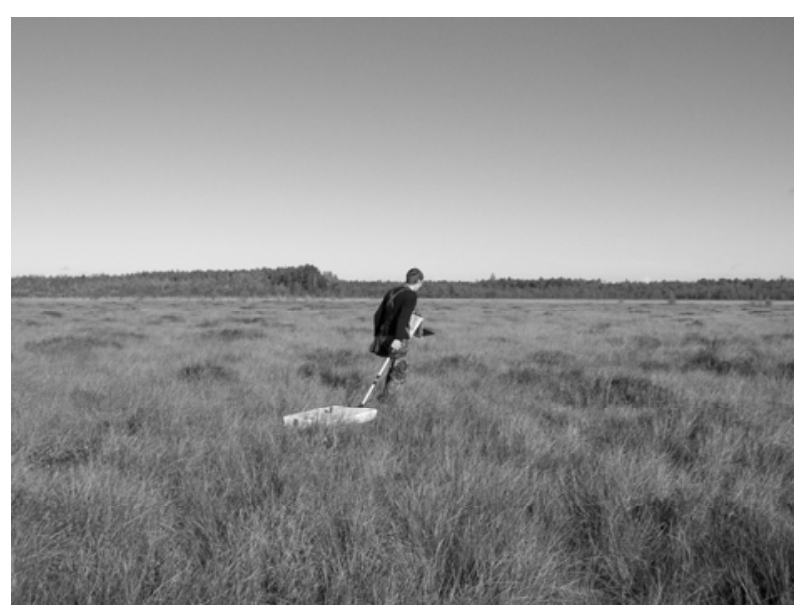

2. att. Radiolokācijas profilēšana Cenas tīrelī. 
Tika izvēlēta profilēšanas metode [9], kas ļauj veikt nepārtrauktu signālu ierakstu un izvēlēto profilu tieši sasaistīt ar urbumu un zondējumu geologiskiem datiem. Ieraksts tika veikts, nepārtraukti fiksējot katru impulsu un izmantojot analogu High-pass frekvenču filtru, ar kura palīdzību tika automātiski dzēsti neinformatīvi signāli. Profilēěsanas laikā georadars ierakstīja 81 zondējumu sekundē. Veiktā radiolokācijas profila garums tika noteikts, izmantojot mērlenti. Ieraksts tika veikts līdz 500 ns laika aizturei, kas atbilst 9,38 m dziļumam, pieņemot, ka grunts pētijumu teritorijā ir kūdra, kurai atbilstošais dielektriskās caurlaidības koeficients ir 64 .

Sākotnēji Cenas tīrelī tika ierakstīiti vairāki radiolokācijas profili, pēc kuru analīzes tika izvēlēta vieta detalizētiem pētījumiem. Detalizēti pētījumi tika veikti vietā, kurai atbilstošajā radarogrammā bija iespējams identificēt signālu, kas saistāms ar purva gultni un vismaz divus subhorizontālus signālus, kas saistāmi ar purva nogulumu slāņu, kuriem ir atšķirīgas elektromagnētiskās īpašības, robežām.

Radiolokācijas profilēšanas gaitā iegūtās radarogrammas tika apstrādātas un analizētas datorprogrammā - Prism 2.5.

Apstrādājot iegūtās radarogrammas, tika izmantota funkcija „gain”, kuru izmantojot iegūtie signāli tika pastiprināti proporcionāli laika aizturei, pēc kuras tie tika saņemti. Izmantojot Ormsbija filtru, tika dzēsti neinformatīvi signāli ar salīdzinoši zemu frekvenci, kas visticamāk ir saistīti ar purva virsmas nelīdzenumiem. Tā kā raidītāja un uztvērēja antenas neatrodas vienā punktā, ir nepieciešams veikt laika korekciju, un tā tika realizēta ar ,,moveout correction” funkciju.

Pētitajā purvā kūdras biezums nav l̦oti liels, kas netieši norāda uz to, ka arī atsevišķi kūdras slāṇi nebūs biezi un līdz ar to zondējošajam signālam būs nepieciešams salīdzinoši mazs laika intervāls, lai šķērsotu atsevišķus nogulumu slāņus. Līdz ar to, ja atsevišķu nogulumu slāņu biezumi tiktu aprēķināti, izmantojot vidējo elektromagnētisko viļ̣nu izplatīšanās ātrumu griezumā, aprēķinātās biezumu vērtības salīdzinoši maz atšķirsies no patiesajām slānuu biezuma vērtībām.

Balstoties uz iepriekšminēto, lai noteiktu dziļumu, no kura saņemti identificētie signāli, tika izmantots vidējais elektromagnētisko vilụnu izplatîšanās ātrums pētītajā griezumā. N̦emot vērā to, ka iegūtajās radarogrammās ir iespējams viennozīmīgi identificèt signālu, kas saistìts ar purva gultni (3. att.), vidējais elektromagnētisko viļ̣nu izplatīšanās ātrums griezumā tika aprēķināts, izmantojot laika aizturi, pēc kuras tika saņemts minētais signāls un pêtījumu teritorijā ierīkotajos urbumos noteiktais purva biezums.

Iegūto radarogrammu analīzes gaitā uzmanība galvenokārt tika pievērsta subhorizontāliem signāliem, kas izsekojami visā profila garumā, jo tieši šãdi signāli ir saistāmi ar izteiktām nogulumu slāņu robežām. Minētajiem signāliem tika noteikta to fāze salīdzinājumā ar signālu, kas ceḷojis tieši no raidītāja uz uztvērēju, kā arī signālu amplitūdas izmainas un identificēšanas iespējas visā profila garumā.

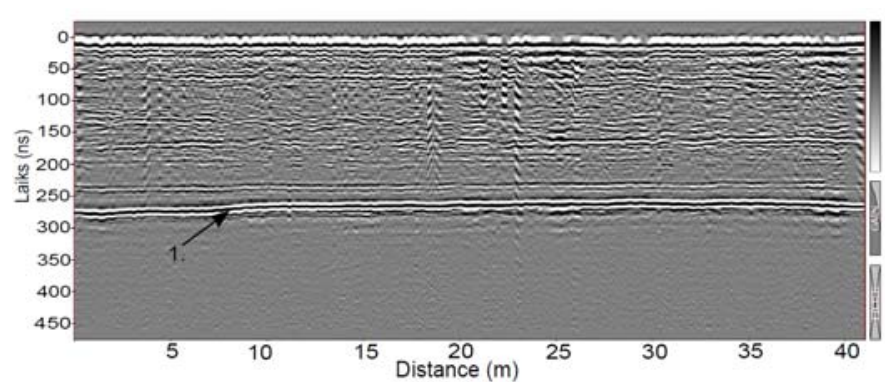

\section{Apzīmējumi \\ 1. $\nearrow_{\text {-identificētais signāls }}$}

3. att. Radarogrammā cena_2-1_300 identificētais signāls, kas saistāms ar purva gultni.

Lai saistītu radiolokācijas profilēšanas gaitā iegūtos signālus ar kūdras īpašǐbu mainu griezumā, pētījumu teritorijā uz profila līnijas tika ierīkoti divi urbumi. Urbumi tika ierīkoti vietās, kur iegūtajā radarogrammā bija iespējams viennozīmīgi identificēt visus radarogrammā sastopamos subhorizontālos signālus. No urbumiem iegūtā serde tika detalizēti aprakstīta un pēc tam laboratorijas apstāklos no tās tika noṇemti paraugi laboratorijas analīzēm, kuru veidi tika izvēlēti, ņemot vērā iepriekšēji veikto pêtījumu rezultātus $[3,4]$. Tas ir - tika apzināti parametri, ar kuru izmaiņām géoloǵiskajā griezumā līdzīga rakstura pētījumos ir tikuši saistîti radiolokācijas signālu atstarojumi. Par tādiem tika noteikti kūdras mitruma daudzums, pelnainība un sadalīšanās pakāpe, bet papildus tika noteikts arī kūdras botāniskais sastāvs.

Kūdras paraugu mitruma daudzums tika noteikts, izmantojot svara zudumu pēc karsēšanas $105^{\circ} \mathrm{C}$ temperatūrā, savukārt kūdras paraugu pelnainība tika noteikta, izmantojot svara zudumu pēc karsēšanas $800^{\circ} \mathrm{C}$ temperatūrā [10]. Mitruma daudzuma un pelnainības analīzes tika veiktas Latvijas Universitātes Ģeogrāfijas un Zemes zinātņu fakultātes Iežu pētījumu un Vides ķīmijas laboratorijā.

Kūdras sadalī̌sanās pakāpe SIA „Vides Konsultāciju Birojs” laboratorijā tika noteikta, izmantojot kūdras botāniskā sastāva analīžu rezultātus [10].

\section{REZULTĀTI}

\section{Laboratorisko pētījumu rezultāti}

Lai saistītu radarogrammā cena_2-1_300 identificētos subhorizontālos signālus ar kūdras īpašību izmaiṇām griezumā, pētijjumu teritorijā tika ierīkoti divi urbumi.

Urbumā U-1, purva gultne tika sasniegta $452 \mathrm{~cm}$ dziḷumā un kūdras paraugi tika iegūti, sākot no $50 \mathrm{~cm}$ dziḷuma, savukārt urbumā U-2 purva gultne tika sasniegta $444 \mathrm{~cm}$ dziļumā un kūdras paraugi tika iegūti, sākot no $60 \mathrm{~cm}$ dziļuma. Urbšanas laikā līdz viena metra dziḷumam, ceḷot ārā urbi, noņemtais kūdras monolīts strauji zaudēja ūdeni, tādēl kūdras paraugos noteiktais mitruma daudzums uzskatāms par korektu, sākot no viena metra dziļuma (4. att.). 


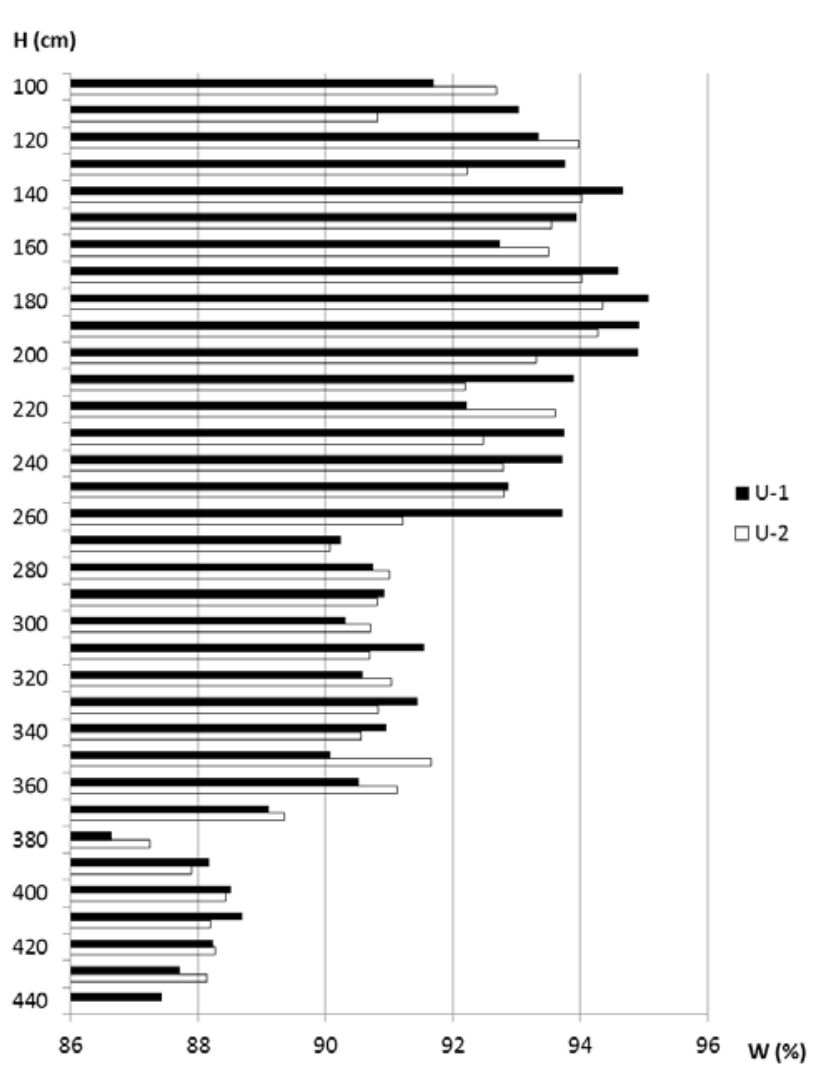

4. att. Mitruma daudzuma izmaiņas U-1 un U-2 urbumu griezumā.

Urbumā U-1 kūdras mitruma daudzums variē intervālā no 86,65 \% līdz 95,73 \% (sk. 4. att.), un pēc š̄i rādītāja izmaiṇām griezumā ir iespējams izdalīt trīs intervālus ar salīdzinoši nemainīgu mitruma daudzumu. Tā intervālā no $100 \mathrm{~cm} \mathrm{līdz}$ $265 \mathrm{~cm}$ dzil̦umam, var izdalīt kūdras slāni ar mitruma daudzumu aptuveni 93,7 \%. Intervālā no $270 \mathrm{~cm} \mathrm{līdz} 375 \mathrm{~cm}$ dziḷumam, var izdalīt otro intervālu, kurā kūdras mitruma daudzums ir aptuveni 90,59 \%. Savukārt trešo intervālu iespējams izdalīt no $390 \mathrm{~cm}$ līdz $445 \mathrm{~cm}$ dziḷumam, kurā kūdras mitruma daudzums ir aptuveni $88,13 \%$, bet $380 \mathrm{~cm}$ dziḷumā apzināts kūdras slānis ar salīdzinoši zemu mitruma daudzumu.

Urbumā U-2 kūdras mitruma daudzums variē intervālā no 87,24 \% līdz 94,35 \% (sk. 4. att.), un arī šajā urbumā atsegtajā purva griezumā ir iespējams izdalīt trīs intervālus ar salīdzinoši nemainīgu kūdras mitruma daudzumu. Tā intervālā no $100 \mathrm{~cm} \mathrm{līdz} 255 \mathrm{~cm}$ dzil̦umam, var izdalīt pirmo intervālu, kurā kūdras mitruma daudzums ir aptuveni 93,16 \%. Intervālā no $260 \mathrm{~cm}$ līdz $375 \mathrm{~cm}$ dziļumam, var izdalìt otro intervālu, kurā kūdras mitruma daudzums ir aptuveni 90,76 \%. Savukārt trešo intervālu iespējams izdalīt no $390 \mathrm{~cm} \mathrm{līdz} 435 \mathrm{~cm}$ dzilımam, kurā kūdras mitruma daudzums ir aptuveni 88,19 \%, un arī šajā griezumā $380 \mathrm{~cm}$ dzil̦umā apzināts kūdras slānis ar salīdzinoši zemu mitruma daudzumu.

Iepriekšêji sniegtais apraksts l̦auj izsekot 4 kūdras slāņus ar atšķirīgu mitruma daudzumu un šo slāṇu robežas uzskatāmas par iespējamām radiolokācijas signāla atstarojuma virsmām.
Kūdras pelnainība tika noteikta, paraugiem aptverot visu purva griezumu, un ir uzskatāma par korekti noteiktu visā urbumu intervālā (5. att.).

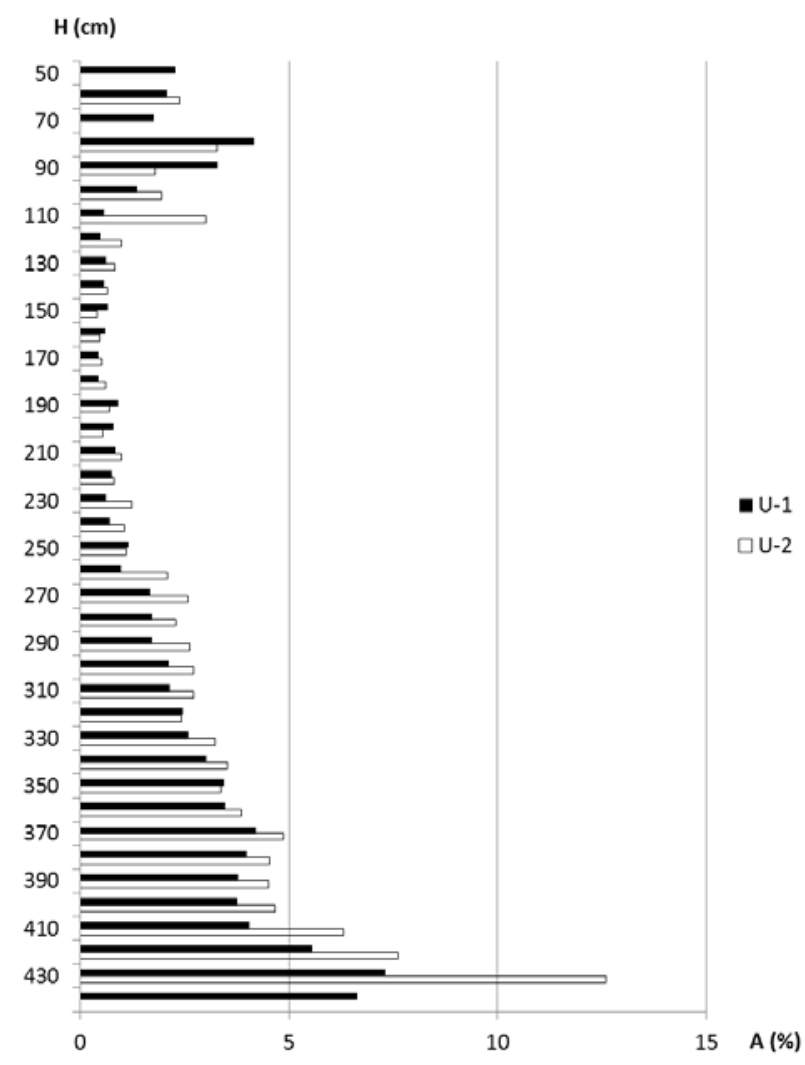

5. att. Kūdras pelnainības izmaiṇas U-1 un U-2 urbumu griezumā.

Urbumā U-1 kūdras pelnainība variē intervālā no 0,43\% līdz 7,3 \% un palielinās līdz ar dziļumu, bet iegūtie analītiskie dati nel̦auj urbuma griezumu sadalīt intervālos ar salīdzinoši nemainīgu pelnainību. Tomēr urbuma U-1 griezumā var izdalīt atsevišksus intervālus ar salīdzinoši nemainīgu kūdras pelnainību. Tā intervālā no $80 \mathrm{~cm}$ līdz $95 \mathrm{~cm}$ dzilumam var izdalīt kūdras slāni ar paaugstinātu pelnu saturu (3,72\%), kā arī intervālā no $370 \mathrm{~cm}$ līdz $415 \mathrm{~cm}$ dziḷumam var izdalīt kūdras slāni ar salīdzinoši nemainīgu pelnu saturu $(3,96 \%)$ (sk. 5. att.).

Urbumā U-2 kūdras pelnainība variē intervālā no $0,41 \%$ līdz 12,61 \% (sk. 5. att.). Kūdras pelnainības izmaiņas urbuma U-2 griezumā ir līdzīgas kā urbuma U-1 griezumā - kūdras pelnainība palielinās, palielinoties dzil̦umam. Urbuma U-2 griezumā var izdalīt atsevišksus kūdras slāṇus ar paaugstinātu pelnainību $-80 \mathrm{~cm}$ un $115 \mathrm{~cm}$ dzilumā. Tāpat griezuma intervālā no $370 \mathrm{~cm}$ līdz $405 \mathrm{~cm}$ dzil̦umam iespējams identificēt kūdras slāni ar salīdzinoši nemain̄̄gu pelnu saturu.

Datu analīze norāda, ka urbumu griezumos nav iespējams izdalīt kūdras slāņus ar krasi atškirīgu pelnu saturu, kas būtu izsekojami visā pētījumu teritorijā. Vien̄̄gais izn̦ēmums ir kūdras slānis ar paaugstinātu pelnu saturu $80 \mathrm{~cm}$ dziḷumā, kura robežas ir uzskatāmas par iespējamām radiolokācijas signāla atstarojuma virsmām (sk. 5. att.). 
Kūdras sadalī̌sanās pakāpe kopumā tika noteikta 46 paraugiem - no urbuma U-1 analīzes tika veiktas 25 paraugiem, bet no urbuma U-2 21 paraugam (6. att.).

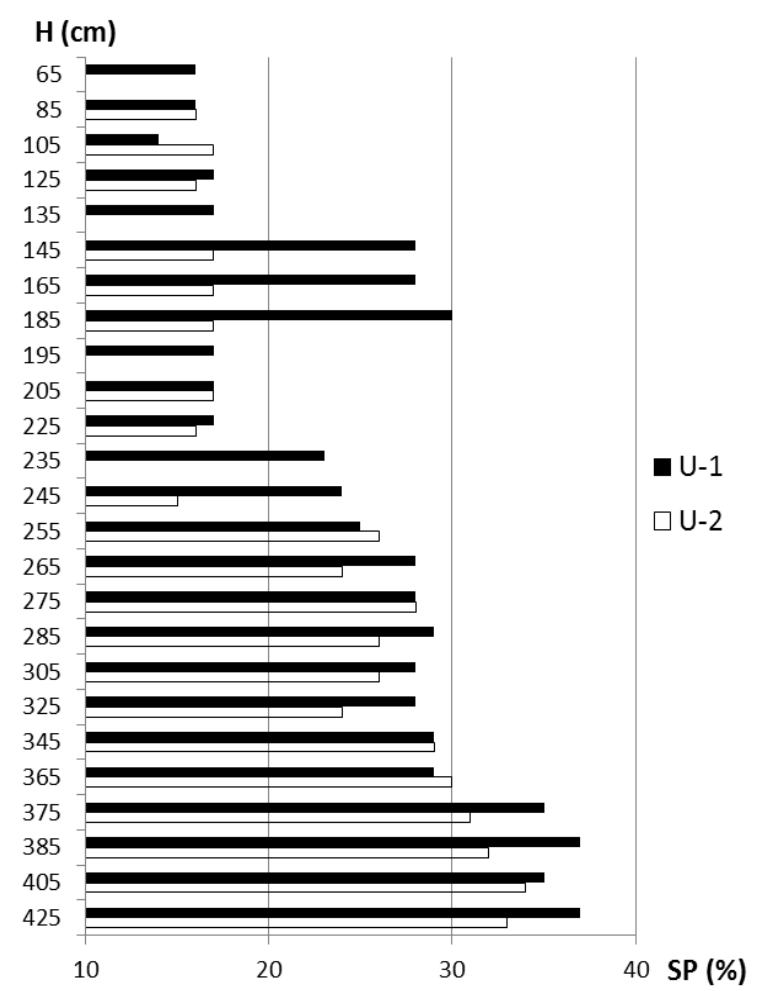

6. att. Kūdras sadalīšanās pakāpes izmaiņas U-1 un U-2 urbumu griezumā.

Urbumā U-1 kūdras sadalīšanās pakāpe variē intervālā no $14 \% \operatorname{lī} \mathrm{dz} 37 \%$ (sk. 6. att.). Urbuma U-1 griezumā pēc sadalīšanās pakāpes ir iespējams izdalīt vairākus slānus, kuros tā ir salīdzinoši nemainīga. Tā intervālā no $65 \mathrm{~cm}$ līdz $140 \mathrm{~cm}$ dziḷumam ir izdalāms nogulumu slānis ar kūdras sadalī̌sanās pakāpi aptuveni 16 \%. Tālāk dziļumā no 145 cm līdz $190 \mathrm{~cm}$ ir izdalāms nogulumu slānis ar salīdzinoši augstu kūdras sadalī̌sanās pakāpi (28,5%). Dzilumāā no $195 \mathrm{~cm}$ līdz $230 \mathrm{~cm}$ ir izdalāms nogulumu slānis ar kūdras sadalīšanās pakāpi $17 \%$, bet intervālā no $235 \mathrm{~cm} \mathrm{līdz} 370 \mathrm{~cm}$ dziḷumam ir izdalāms nogulumu slānis ar salīdzinoši nemainīgu kūdras sadalī̌sanās pakāpi (27\%). Raksturīgi, ka minētajā intervālā, palielinoties dzilumam, kūdras sadalī̌sanās pakāpe palielinās. Dziḷumā no $375 \mathrm{~cm} \mathrm{līdz} 430 \mathrm{~cm}$ ir izdalāms nogulumu slānis ar kūdras sadalīšanās pakāpi $36 \%$, kas ir maksimālā apzinātā šî lieluma vērtība urbuma U-1 griezumā.

Urbumā U-2 kūdras sadalīšanās pakāpe variē intervālā no $15 \% \operatorname{li} \mathrm{dz} 34 \%$ (sk. 6. att.). Urbuma U-2 griezumā pēc sadalīšanās pakāpes ir iespējams izdalīt divus slāņus. Intervālā no $85 \mathrm{~cm}$ līdz $250 \mathrm{~cm}$ dziļumam ir izdalāms nogulumu slānis ar kūdras sadalīšanās pakāpi aptuveni 16,4 \%, kas variē salīdzinoši maz visā izdalītajā intervālā. Intervālā no $255 \mathrm{~cm}$ līdz $430 \mathrm{~cm}$ dziļumam ir izdalāms nogulumu slānis ar salīdzinoši nemain̄̄gu kūdras sadalīšanās pakāpi, kas ir vienāda ar aptuveni 28,5 \%. Izdalītajā intervālā, palielinoties dzilıumam, kūdras sadalīšanās pakāpe palielinās.
Iepriekšēji sniegtais raksturojums norāda, urbumu U-1 un U-2 griezumos, pēc kūdras sadalīšanās pakāpes rādītāja, ir iespējams identificēt kūdras slāṇu robežas ar krasām sadalīšanās pakāpes izmaiñām, kas ir izsekojamas visā pêtījumu teritorijā. Tā urbumā U-1 $235 \mathrm{~cm}$ dziļumā vērojama krasa kūdras sadalīšanās pakāpes palielināšanās, kā arī urbumā U-2 $255 \mathrm{~cm}$ dziḷumā identificējama krasa kūdras sadalīšanās pakāpes palielināšanās (sk. 6. att.). Identificētā robeža uzskatāma par iespējamu radiolokācijas signāla atstarojuma virsmu. Urbumā U-1 dziļumā no $145 \mathrm{~cm} \operatorname{līdz} 190 \mathrm{~cm}$ identificētā nogulumu slāņa ar salīdzinoši augstu kūdras sadalī̌̌anās pakāpi robežas vismaz lokāli var tikt uzskatītas par iespējamām radiolokācijas signāla atstarojuma virsmām. Līdzīgi par lokālu iespējamu atstarojuma virsmu var tikt uzskatīta U-1 urbumā konstatētā robeža starp kūdras slāņiem ar atšķirīgu sadalīšanās pakāpi $375 \mathrm{~cm}$ dzilıumā.

\section{Iegūtās radarogrammas analīze}

Visas pētījuma gaitā iegūtās radarogrammas bija kvalitatīvas un izmantojamas tālākai datu apstrādei un interpretācijai. Detalizēta analīze tika veikta radarogrammai cena 2-1 300 (7. att.).

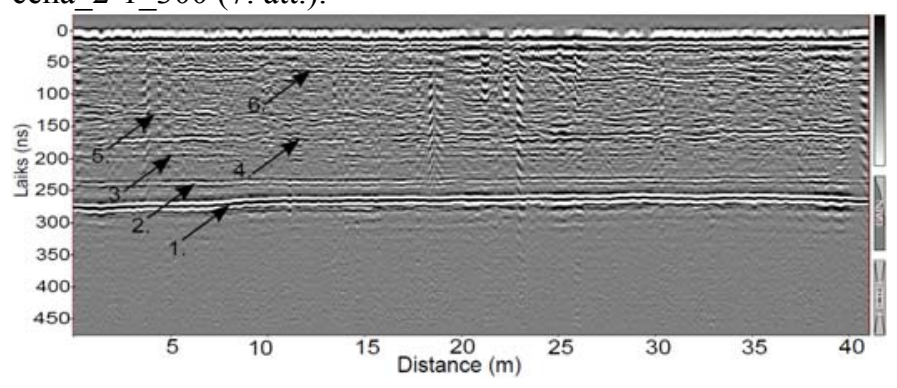

Apzīmējumi

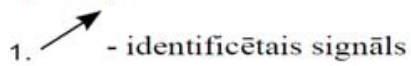

7. att. Radarogrammā cena_2-1_300 identificētie informatīvie signāli.

Iegūtajā radarogrammā informatīvie signāli ir identificējami līdz pat 310 ns laika aizturei, un šajā intervālā ir iespējams identificēt sešus subhorizontālus signālus, kas saistīti ar robežām, kas nošķir nogulumu slāņus ar atšķirīgām elektromagnētiskajām īpašībām (sk. 7. att.).

1. signāls ir izsekojams visā radarogrammā, un tam ir salīdzinoši liela amplitūda, kas norāda uz to, ka minētais signāls ir saistīts ar izteiktām nogulumu elektromagnētisko īpašību izmaiņām (sk. 7. att.). Raksturīgi, ka aprakstītais signāls visā profila garumā ir vienā fāzē ar tiešo signālu. Tas norādu uz to, ka nogulumu slānim, kas paguḷ robežai, kas saistīta ar šo signālu, ir mazāks vides dielektriskās caurlaidības koeficients nekā uzguḷošajam nogulumu slānim. N̦emot vērā aprakstītās signāla īpašības, tas tiek saistīts ar purva gultni.

Otrais (2) signāls ir izsekojams visā radarogrammā, tomēr atsevišķās vietās tā amplitūda ir salīdzinoši neliela (sk. 7. att.). Signāla amplitūdas lokālās izmaiņas visdrīzāk ir saistītas ar grūtībām profilēšanas laikā nodrošināt antenu pastāvīgu un ciešu kontaktu ar grunts virskārtu. N̦emot vērā minētā signāla amplitūdas lielumu, var secināt, ka signāls ir saistīts ar robežu, kas nošķir kūdras slāņus ar izteikti atšķirīgām 
elektromagnētiskajām īpašībām. Aprakstītais signāls visā profila garumā ir pretējā fāzē ar tiešo signālu, kas norādu uz to, ka nogulumu slānim, kas pagul robežai, kas saistīta ar šo signālu, ir lielāks vides dielektriskās caurlaidības koeficients nekā uzgul̦ošajam nogulumu slānim.

Trešā (3) signāla izsekošana visā profila garumā ir apgrūtināta (sk. 7. att.). Atsevišķāàs radarogrammas vietās signāls nav identificējams (piemēram, pie $11 \mathrm{~m}$ un $33 \mathrm{~m}$ atzīmes), un tā amplitūda kopumā ir salīdzinoši neliela, kas norāda uz signāla saistību ar nelielām elektromagnētisko īpašību izmaiñām pētītajā ǵeoloǵiskajā griezumā. Aprakstītā signāla polaritātes identificēšana ir neviennozīmīga, tomēr kopumā ir konstatējams, ka signāls ir pretējā fāzē ar tiešo signālu, kas norādu uz to, ka nogulumu slānim, kas piegul robežai, kas saistīta ar šo signālu, ir lielāks vides dielektriskās caurlaidības koeficients nekā uzguḷošajam nogulumu slānim.

Ceturtais (4) signāls ir izsekojams visā radarogrammā, tam raksturīgās amplitūdas variācijas ir salīdzinoši lielas, un tās nav iespējams skaidrot tikai ar antenas kontakta ar grunts virskārtu izmain̄ām (sk. 7. att.). Signāla raksturojums norāda, ka tas ir saistāms ar robežu starp diviem nogulumu slāņiem, kuru elektromagnētisko īpašību atšksirības visā profila garumā nav konstantas. Aprakstītais signāls visā profila garumā ir pretējā fāzē ar tiešo signālu, kas norādu uz to, ka nogulumu slānim, kas pagul robežai, kas saistīta ar šo signālu, ir lielāks vides dielektriskās caurlaidības koeficients nekā uzguḷošajam nogulumu slānim.

Piektais (5) signāls ir izsekojams līdz $21 \mathrm{~m}$ profila garuma atzīmei, kur tas vairs nav izšķirams ar 4. signālu (sk. 7. att.). N̦emot vērā, ka signāls izsekojams tikai daļā no radarogrammas, tas saistāms ar robežu starp nogulumu slāņiem, kas nav izplatīti visā pētījumu teritorijā. Minētajam signālam ir raksturīgas lielas amplitūdas svārstības visā profila garuma intervālā, kur tas izsekojams. Amplitūdas svārstību iemesli skaidrojami līdzīgi kā iepriekš aprakstītajam 4. signālam. Aprakstītais signāls visā intervālā, kurā to iespējams identificēt, ir pretējā fāzē ar tiešo signālu, kas norādu uz to, ka nogulumu slānim, kas paguḷ robežai, kas saistîta ar šo signālu, ir lielāks vides dielektriskās caurlaidības koeficients nekā uzgulošajam nogulumu slānim.

Visā profila garumā, aptuveni pēc 60 ns laika aiztures, ir identificējami vairāki subhorizontāli signāli, kurus var apvienot 6. signālā (sk. 7. att.). N̦emot vērā, ka signālam ir salīdzinoši liela amplitūda, bet tas ir grūti izsekojams visā radarogrammas garumā, signāls domājams ir saistīts ar lokālām elektromagnētisko īpašību izmaiṇām griezumā, kas sastopamas aptuveni vienādā dziḷumā. Minētajam signālam korekta polaritātes noteikšana nav iespējama.

Izmantojot noteikto purva nogulumu biezumu urbumos U-1 un U-2, kā arī laika aizturi, pēc kuras tika saņemts signāls no purva gultnes urbumiem atbilstošajās vietās, tika aprēķināts, ka vidējais elektromagnētisko viḷnu izplatîšanās ātrums purva nogulumos pētījumu teritorijā ir $34850165 \mathrm{~m} / \mathrm{s}$ un tam atbilstošais vides dielektriskās caurlaidības koeficients ir vienāds ar 74. Izmantojot iegūto vides dielektriskās caurlaidības koeficienta vērtību radiolokācijas profilēšanas laikā iegūtās laika aiztures vērtības, ar datorprogrammu Prism 2.5 tika pārrēķinātas dziļuma vērtībās (8. att.).

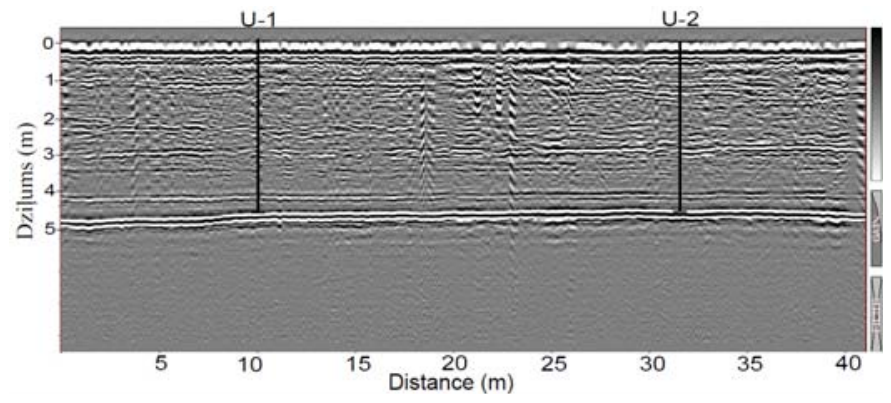

Apzīmējumi

U-2

$L^{-2}$ - urbuma novietojums

8. att. Radarogramma cena_2-1_300 ar pētījumu teritorijā izvietotajiem urbumiem.

Iegūto radiolokācijas signālu sasaiste ar nogulumu īpašību maiņu griezumā

Balstoties uz radarogrammu cena_2-1_300, tika noteikts dziļums, no kāda saṇemti signāli, kas saistāmi ar kūdras slāṇu robežām ( sk. 8. att., 9. att., 10. att.).

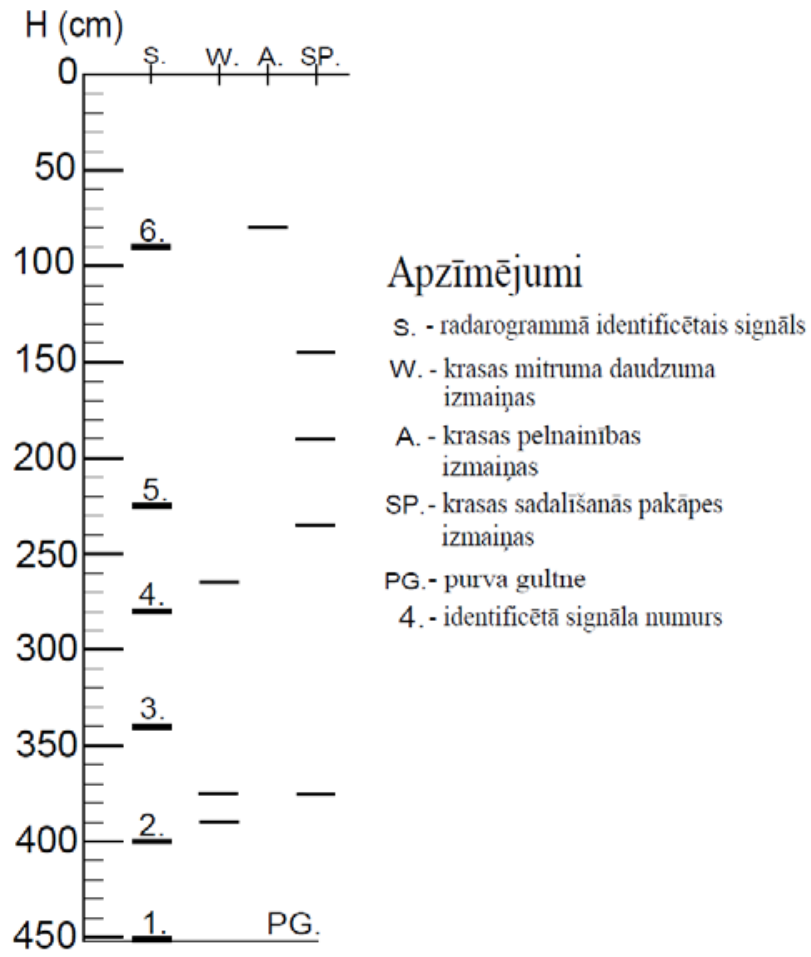

9. att. Iegūto signālu sasaiste ar kūdras īpašību izmaiṇām urbuma U-1 griezumā.

8. un 9. attēlā atspogulotie dati norāda, ka urbumam U-1 atbilstošajā vietā iegūtos radiolokācijas signālus nav iespējams skaidrot tikai ar kūdras mitruma daudzuma izmain̄ām griezumā. Signāli, kas varētu būt saistīti ar kūdras mitruma daudzuma izmain̄ām griezumā, ir 2. un 4. signāls, bet signāli 3., 5. un 6. nevar tikt skaidroti ar mitruma izmaināām (sk. 9. att.). 
Iegūtos signālus nav iespējams viennozīmīgi sasaistīt tikai ar kūdras sadalīšanās pakāpes izmaiṇām griezumā. Analizējot kūdras sadalīšanās pakāpes izmaiņas urbuma U-1 griezumā, tika identificētas 4 iespējamās signāla atstarojuma virsmas, taču tikai 5. signāls ir saistāms ar vienu no šīm virsmām $235 \mathrm{~cm}$ dziḷumā. Pārējās trīs raksturīgās īpašību robežas (145, 190 un $375 \mathrm{~cm}$ dzil̦umā) nav iespējams saistît ar iegūtajiem radiolokācijas signāliem (sk. 9. att.).

Iespējams, ka radarogrammā identificētais 6. signāls ir saistīts ar urbuma U-1 griezumā konstatēto slāni ar paaugstinātu pelnu saturu $80 \mathrm{~cm}$ dziḷumā.

Līdzīgi arī urbumam U-2 atbilstošajā vietā iegūtos radiolokācijas signālus nav iespējams skaidrot tikai ar kūdras mitruma daudzuma izmain̄ām griezumā (sk. 10. att.).

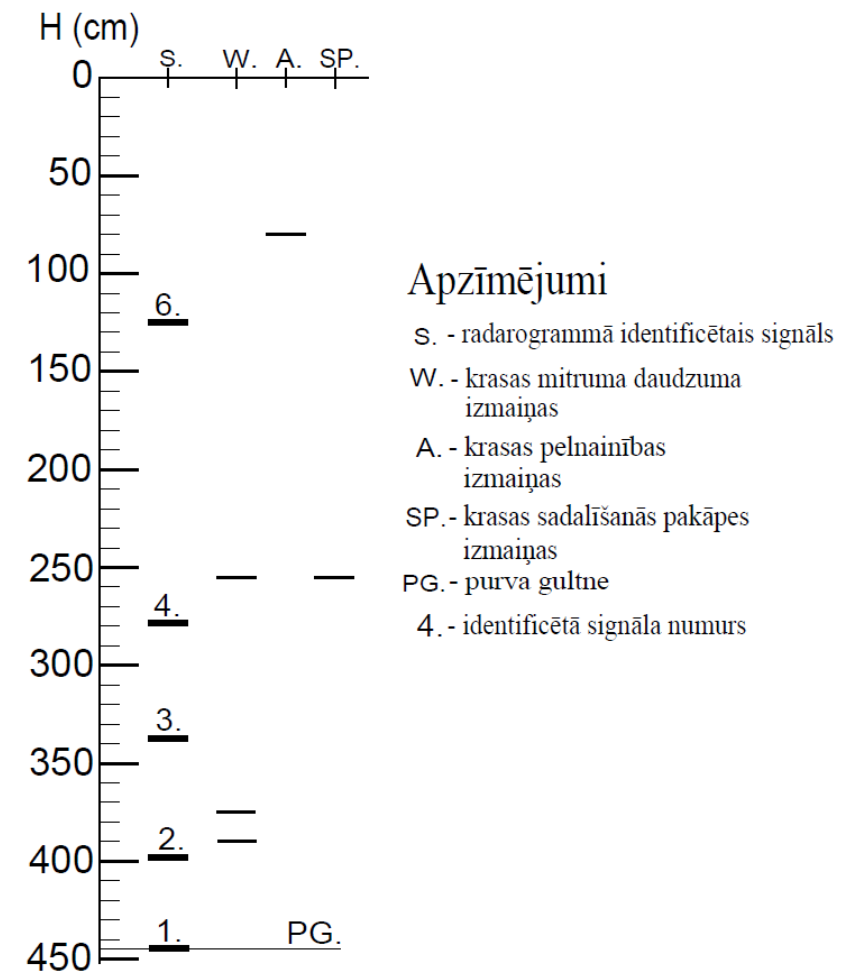

10. att. Iegūto signālu sasaiste ar nogulumu īpašǐbu izmaiņām urbuma U-2 griezumā.

Kā signāli, kas varētu būt saistīti ar kūdras mitruma daudzuma izmain̄ām urbuma U-2 griezumā, jāmin 2. un 4. signāls, bet signāli 3. un 6 . nevar tikt skaidroti ar mitruma izmain̄ām (sk. 10. att.). Šajā urbuma griezumā tika izdalīti 2 nogulumu slāņi ar atšķirīgu kūdras sadalīšanās pakāpi, kuru robeža identificēta $255 \mathrm{~cm}$ dziḷumā, un iespējams, ka 4. radiolokācijas signāls ir saistîts ar minēto robežu, bet atlikušie radiolokācijas signāli (1., 2., 3., 6.) nevar tikt skaidroti ar kūdras sadalīšanās pakāpes izmaiņām griezumā. Savukārt $80 \mathrm{~cm}$ dziḷumā identificēto kūdras slāni ar paaugstināto pelnu saturu nav iespējams droši sasaistīt ne ar vienu no iegūtajiem radiolokācijas signāliem.

\section{DISKUSIJA}

Balstoties uz citu pētnieku rekomendācijām [6,7,8], pētījumā tika izmatota $300 \mathrm{MHz}$ antenu sistēma, un arī šajā pētījumā iegūtie rezultāti norāda, ka līdzīgu purva nogulumu pētījumu veikšanai minētā antenu sistēma uzskatāma par piemērotu. Sagaidāms, ka ar $300 \mathrm{MHz}$ antenu sistēmu purva nogulumos ir iespējams iegūt informatīvus signālus vismaz līdz 4,5 m dziḷumam.

Elektromagnētisko viḷnu izplatīšanās ātrums pētîjumu teritorijā sastopamajos kūdras slāņos tika noteikts, izmantojot urbumu datus un laika aizturi, pēc kuras iegūti radiolokācijas signāli - tiek izmantots vidējais elektromagnētisko viḷnu izplatǐšanās ātrums. Aprēḳinātā vides dielektriskās caurlaidības koeficienta vidējā vērtība ir vienāda ar 74, kas kopumā uzskatāma par atbilstošu un raksturīgu purvu nogulumiem [11].

Dziḷums, no kāda iegūti radiolokācijas signāli, tika aprēķināts, izmantojot vidējo elektromagnētisko viļnu izplatīšanās ātrumu griezumā. Izmantotā metode uzskatāma par pietiekami precīzu, gadījumos, kad pētījumu teritorijā, izmantojot kūdras īpašības, iespējams izdalīt tikai dažus kūdras slāņus, kā arī tiek analizētas tikai atsevišķas kūdras īpašības. Gadījumos, kad pēc īpašībām izdalāmi vairāki kūdras slāṇi, griezumā tiek identificētas vairākas robežas, kas var būt radiolokācijas signāla atstarojuma virsmas. Tādēl, lai būtu iespējams veikt korektu iegūto signālu korelāciju ar kūdras īpašību maiņu griezumā, dziḷumu, no kāda saņemti iegūtie signāli, jānosaka ar augstu precizitāti, izmantojot kopējā viduspunkta metodi [11]. Vairāki līdzīgu pētījumu autori izmanto un turpmākiem pētījumiem iesaka aprēķinos izmantot tikai vidējo elektromagnētisko viḷnu izplatīšanās ātrumu griezumā $[4,12]$. Tomēr veiktā pētījuma rezultāti liecina, ka, lai korekti interpretētu iegūtos radiolokācijas signālus, ir jāpielieto kopējā viduspunkta metodi.

Balstoties uz pētījuma laikā veikto kūdras īpašību analīžu rezultātiem, tika konstatēts, ka pētījumu teritorijā ir iespējams izdalīt atsevišķus kūdras slāņus pēc to mitruma daudzuma. Tā pētījumu teritorijā ir iespējams izdalīt četrus kūdras slāņus ar atšksirīgu mitruma daudzumu. Minētie slāņi ir izsekojami visā pētījumu teritorijāa, un līdz ar to šo slānu robežas ir uzskatāmas par iespējamām radiolokācijas signāla atstarojuma virsmām. Tomēr, veicot iegūto radiolokācijas signālu un kūdras slāṇu ar atšķirīgu mitruma daudzumu robežu korelāciju, tika konstatēts, ka tikai dažus no iegūtajiem signāliem ir iespējams skaidrot ar mitruma daudzuma izmain̄ām griezumā. Līdz ar to vairāku līdzịu pētījumu autoru paustais viedoklis [2,3,8], ka purvu nogulumos iegūtie radiolokācijas signāli ir saistīti galvenokārt tikai ar mitruma izmaiņām griezumā, nav korekts.

Zināms, ka grunts minerālajām dal̦in̄ām, salīdzinot ar ūdeni, ir ievērojami zemāks vides dielektriskās caurlaidības koeficients [11], kas nozīmē to, ka pat nelielas mitruma daudzuma izmaiņas būtiski ietekmē elektromagnētisko viļ̣nu izplatīšanās âtrumu nogulumos. Tomēr pētījumā iegūtie rezultāti norāda, ka kūdras kopējā mitruma daudzuma izmaiņas pētījuma teritorijā ne vienmēr ierosina radiolokācijas signāla atstarojumu. Iespējams, ka detalizētāka atsevišķu ūdens veidu kūdrā analīze varētu sniegt kādu pamatotāku skaidrojumu, jo, piemēram, saistītā ūdens vides dielektriskās caurlaidības koeficients krasi atšksiras no brīvā ūdens vides dielektriskās caurlaidības koeficienta [13]. 
Izmantojot pētījuma laikā veikto kūdras īpašību analīžu rezultātus, tika konstatēts, ka pētījumu teritorijā kūdras pelnainības izmaiṇas griezumā ir vienmērīgas. Rezultātā pētījumu teritorijā nav iespējams izdalīt kūdras slāņus, izmantojot nogulumu pelnainību. Kā izṇēmums ir atzīmējams kūdras slānis $80 \mathrm{~cm}$ dziḷumā, kam ir salīdzinoši augstāks pelnu saturs. Radarogrammā identificēto 6. signālu urbumam U-1 atbilstošajā vietā ir iespējams saistīt ar minēto kūdras slāni, bet urbumam U-2 atbilstošajā vietā 6 . signāls tika saṇemts no lielāka dziḷuma $(125 \mathrm{~cm})$. Līdz ar to pētījumu teritorijā iegūtie signāli nevar tikt saistīti ar kūdras pelnainības izmain̄ām griezumā, kas, pēc vairāku līdzịgu pētījumu autoru domām [4], var ierosināt radiolokācijas signāla atstarojumu. Tomēr jāatzīmē, ka dzil̦uma, no kāda saṇemts 6 . signāls, noteikšana nebija viennozīmīga un rezultātā tālāka signāla korelācija ar nogulumu īpašîbu izmaiņām griezumā nav uzskatāma par precīzu un pamatotu.

Balstoties uz pētījuma laikā veikto kūdras analīžu rezultātiem, konstatēts, ka pētījumu teritorijā ir iespējams izdalīt atsevišksus nogulumu slāņus pēc kūdras sadalīšanās pakāpes, bet visā pētījumu teritorijā ir izsekojama tikai viena robeža starp nogulumu slāņiem ar atšksirīgu kūdras sadalīšanās pakāpi. Identificētā robeža urbumā U-1 tika konstatēta $235 \mathrm{~cm}$ dziļumā, kas atbilst 5. radiolokācijas signālam, bet urbumā U-2 tā tika konstatēta $255 \mathrm{~cm}$ dziļumā, kas atbilst 4. radiolokācijas signālam. Tādējādi minēto robežu nav iespējams sasaistīt ar kādu no radarogrammā identificētajiem subhorizontālajiem signāliem. Vienlaicīgi iegūtajā radarogrammā netika identificēti signāli, kas būtu saistāmi ar kūdras sadalīšanās pakāpes lokālajām izmaiṇām urbuma U-1 griezumā. Citu līdzīgu pētījumu autori ir atzīmējuši [4,5], ka kūdras sadalīšanās pakāpes izmaiņas griezumā vairumā gadījumu ierosina radiolokācijas signāla atstarojumu, taču veiktā pētījuma rezultāti liecina, ka pat salīdzinoši krasas kūdras sadalī̌sanās pakāpes izmaiņas griezumā var arī neierosināt radiolokācijas signāla atstarojumu.

Analizējot iegūtos radiolokācijas signālus, uzmanība tika pievērsta signālu amplitūdai un tās izmaiņām radarogrammā visā profila garumā. Konstatēts, ka signāli, kas iegūti no lielāka dziḷuma, ir ar salīdzinoši nemainīgu amplitūdu un tos ir iespējams identificēt visā radarogrammā. Minētais norāda, ka kūdras slāṇi ir izturēti un to īpašības ir salīdzinoši nemainīgas visā pētījumu teritorijā. Signāliem no neliela dziļuma, pretēji raksturīgas amplitūdas izmaiņas plašā intervālā un atsevišksās radarogrammas vietās šo signālu identificēšana ir apgrūtināta.

Kopumā šāds signālu raksturs norāda uz kūdras slāṇu heterogenitāti un tā pētītajā teritorijā novērojama $\operatorname{li} \mathrm{dz} 260 \mathrm{~cm}$ dziļumam. Savukārt radarogrammā identificētie signāli liecina par izteiktu kūdras heterogenitāti aptuveni līdz trīs metru dziļumam. Tādējādi, balstoties uz minēto radiolokācijas signālu amplitūdas raksturojumu un iegūtajiem kūdras analīžu rezultātiem, pētījumā tika apstiprināta hipotēze par iespējām pēc radiolokācijas signāla amplitūdas raksturot kūdras slāṇu ipašības.
Analizējot iegūtos radiolokācijas signālus, tika vērtēta to polaritāte un tās izmaiṇas, salīdzinot ar signālu, kas cel̦ojis tieši no raidītāja uz uztvērēju.

Kopumā iegūto signālu polaritātes noteikšana vairumā gadījumu ir viennozīmīga, tomēr tās noteikšana ir apgrūtināta signāliem ar sal̄̄dzinoši zemu amplitūdu, kā arī signāliem, kurus ir grūti izškirt. Iegūtajā radarogrammā identificētais 1. signāls (sk. 7. att.), kas tika saistīts ar purva gultni, ir vienā fāzē ar tiešo signālu. Tas bija sagaidāms, jo elektromagnētisko vilụu izplatīšanās àtrums purva nogulumos ir mazāks nekā elektromagnētisko viḷnu izplatīšanās ātrums smilšainos nogulumos [11]. Radarogrammā identificētais 2. signāls tika saistīts ar mitruma daudzuma izmaiñām griezumā - tas ir ar robežu starp diviem kūdras slān,iem, kur paguḷošā slāṇa mitruma daudzums ir lielāks nekā uzgulošā slāņa mitruma daudzums. Balstoties uz to, ka, palielinoties mitruma daudzumam, elektromagnētisko viḷnu izplatīšanās ātrums grunts slānī samazinās [11], minētajam signālam būtu jābūt pretējā fāzē ar tiešo signālu, kas arī tika konstatēts. Līdz ar to pêtījuma laikā tika apstiprināts, ka iegūto signālu polaritāti var izmantot kūdras slāṇu dielektriskās caurlaidības vērtību savstarpējai salīdzināšanai.

\section{SECINĀJUMI}

Veiktais pētījums parāda, ka kūdras pētījumos ar radiolokācijas metodi elektromagnētisko viḷnu izplatīšanās àtrums kūdras slān,os jānosaka ar augstu precizitāti, izmantojot kopējā viduspunkta metodi. Vidējās ātruma vērtības izmantošana ir attaisnojama tikai atsevišķos gadījumos, kad iegūtajiem ǵeofizikālajiem mērījumiem nav nepieciešama augsta precizitāte.

Izmantojot iegūto signālu amplitūdu un polaritāti, var noteikt kūdras slāṇu īpašības un savstarpēji salīdzināt to vides dielektriskās caurlaidības koeficientus.

Līdzšinējos pētījumos dominējošais secinājums, ka elektromagnētisko viḷnu izplatī̌sanās ātrumu kūdrā nosaka tikai kūdras mitruma daudzuma izmaiņas, ir kḷūdains. Veiktais pētījums norāda, ka šīs atkarības ir ievērojami komplicētākas, tomēr vienkāršotiem lietišķiem un aptuveniem aprēķiniem tās var tikt izmantotas arī turpmāk.

\section{PATEICĪBAS}

Pētījums izstrādāts ar LZP granta „Latvijas minerālie resursi un inovatīvi funkcionāli materiāli uz minerālo un sintētisko izejvielu bāzes” (09.1553.3), VPP „Vietējo resursu (zemes dzīḷu, meža, pārtikas un transporta) ilgtspējīga izmantošana - jauni produkti un tehnoloǵijas (NatRes)" apakšprojekta Nr.1 „Jaunu tehnolog̣iju izstrādāšana inovatīvu produktu radīšanai no Latvijas zemes dzịlı resursiem (ZEMES DZĪLES)” un ESF projekta „Atbalsts doktora studijām Latvijas Universitātē - 2" (Nr. 2011/0054/1DP/1.1.2.1.2/11/IPIA/VIAA/002) atbalstu.

\section{LITERATŪRAS SARAKSTS}

[1] Bogorodskijs, V.V., Trepovs, G.V. Kūdras un sapropeḷa iegulu biezuma mērījumi ar radiolokācijas metodi. Tehniskās fizikas žurnāls, 1979, s. 49, 670 - 673 lpp. 
[2] Comas, X., Slater, L., Reeve, A. Pool patterning in a northern peatland: Geophysical evidence for the role of postglacial landforms. Journal of $\begin{array}{llll}\text { Hydrology, 2011, vol. } 399, & \text { p. } & 173-184 .\end{array}$ http://dx.doi.org/10.1016/j.jhydrol.2010.12.031

[3] Plado, J., Sibul, I., Mustasaar, M., Joeleht, A. Ground - penetrating radar study of the Rahivere peat bog, eastern Estonia. Estonian journal of earth sciences, 2011, vol. 60, p. $31-42$.

[4] Slater, L.D., Reeve, A. Case history: investigating peatland stratigraphy and hydrogeology using integrated electrical geophysics. Geophysics, 2002, vol. 67, p. 365-378. http://dx.doi.org/10.1190/1.1468597

[5] Kettridge, N., Comas, X., Baird, A., Slater, L., Strack, M., Thompson, D., Jol, H., Binley, A. Ecohydrologically important subsurface structures in peatlands revealed by ground-penetrating radar and complex conductivity surveys. Journal of Geophysical Research, 2008, vol. 113, G04030. doi:10.1029/2008JG000787.

[6] Musgrave, H., Binley, A. Revealing the temporal dynamics of subsurface temerature in a wetland using tike-lapse geophysics. Journal of Hydrology, 2011, vol. 396, p. 258-266. http://dx.doi.org/10.1016/j.jhydrol.2010.11.008

[7] Van Bellen, S., Dallaire, P.L., Garneau, M., Bergeron, Y. Quantifying spatial and temporal Holocene carbon accumulation in ombrotrophic peatlands of the Eastmain region, Quebec, Canada. Global Biogeochem. Cycles, 2011, vol. 25, GB2016, doi:10.1029/2010GB003877. http://dx.doi.org/10.1029/2010GB003877

[8] Holden, J., Burt, T.P., Vilas, M. Application of ground-penetrating radar to the identification of subsurface piping in blanket peat. Earth Surface Processes and Landforms, 2002, vol. 27, p. 235-249. http://dx.doi.org/10.1002/esp.316

[9] Reynolds, M.J. An Introduction to Applied and Environmental Geophysics. West Sussex, John Wiley \& Sons, 1997, p. $682-745$.
[10] Krūmiņš, J., Silamiķele, I., Purmalis, O., Stankeviča, K., Kušķe, E., Pujāte, A., Ozola, I., Ceriṇa, A., Rūtinna, L., Stivriṇš, N. Kūdras un sapropel̦ pētījumu metodes. Latgales druka, Rīga, 2012. 80 lpp.

[11] Neal, A. Ground-penetrating radar and its use in sedimentology: principles, problems and progress. Earth-Science Reviews, 2004, vol. 66, p. 261-330. http://dx.doi.org/10.1016/j.earscirev.2004.01.004

[12] Oliveira, M., Porsani, J., Lima, G., Jeske-Pieruschka, V. \& Behling, H. Upper Pleistocene and Holocene peatland evolution in Southern Brazilian highlands as depicted by radar stratigraphy, sedimentology and palynology. Quaternary Research, 2012, vol. 77, p. 397 - 407. http://dx.doi.org/10.1016/j.yqres.2011.12.006

[13] Bojarskijs, D.A., Tihonovs, V.V. Saistītā üdens ietekme uz mitru un sasalušu grunšu dielektrisko caurlaidību. Maskava, Kosmisko pētījumu institūts RAN, 2003, 48 lpp.

\section{Jānis Karušs, Mg.geol. 2012, Dr.geol. stud.}

Current position: Scientific assistant of the Department of Applied geology at the Faculty of Geography and Earth Sciences at the University of Latvia. His major fields of study are ground penetrating radar and its application possibilities in peatland and clay deposits

Address: Alberta 10, Riga, LV 1010, Latvia.

e-mail: janis.karuss@inbox.lv

Valdis Seglins. Dr. geol., University of Latvia, Faculty of Geography and Earth Sciences, Department of Geology, author of up to 300 scientiefic publications in area of Earth Sciences.

Address: Raiņa bulv. 19, LV1050, Riga, Latvia.

Phone +37167331, Fax: +371 67332704

e-mail: valdis.seglins@lu.lv

\section{Jānis Karušs, Valdis Seglinšs. The Analysis of Ground Penetrating Radar Signals Acquired in Cenas Tirelis}

This research is devoted to the analysis and interpretation of ground penetrating radar signals obtained in bog deposits. Research goals are to find out peat physical properties that mainly determine peat electromagnetic properties and also to identify reflected ground penetrating radar signal properties and offer their geological interpretation.

This paper includes the description of research area geological structure, description of applied ground penetrating radar research methodology, results of peat humification analysis, results of organic matter content and moisture content analysis. In addition, the paper deals with the detailed ground penetrating radar signal analysis, which includes the analysis of amplitude and phase of the obtained ground penetrating radar signals. Attention was also paid to possibilities to identify the obtained ground penetrating radar signals.

The results obtained in this research indicate that $300 \mathrm{MHz}$ antenna system is applicable to performing similar studies. It is expected that with $300 \mathrm{MHz}$ antenna system informative ground penetrating radar signals will be obtained from the depth of 4.5 meters. Data analysis shows that in boreholes it is possible to identify 4 peat layers with different moisture content, that are traceable throughout research area. Boundaries between these layers are considered to be possible reflection surfaces of ground penetrating radar signal. It is also possible to trace boundaries between peat layers with different degree of humification throughout research area. Boundaries between peat layers with different ash content which are traceable throughout research area were not identified in this research.

It is concluded that an electromagnetic wave propagation speed in peat layers must be determined with high precision using a common midpoint method and in previous studies the opinion has been expressed that an electromagnetic wave propagation speed in peat layers determines only moisture content is incorrect.

\section{Янис Карушс, Валдис Сеглиньш. Анализ радиолокационных сигналов, полученных в болоте "Ценас"}

Исследование посвящено анализу и интерпретации радиолокационных сигналов, полученных в болотных отложениях. Цель исследования - выявить физические свойства торфа, которые главным образом определяют электромагнитные свойства торфа, а так же идентифицировать свойства отраженных сигналов и предоставить их геологическую интерпретацию. Дано описание геологического строения изучаемой территории, а так же, описание используемой методики радиолокационных исследований, результаты анализов степени разложения, содержания пепла и естественной влажности торфа. Так же представлен детальный анализ полученных радиолокационных сигналов, в котором рассмотрена амплитуда и полярность сигналов, а так же возможности их идентификации на полученных радиограммах. Результаты исследования показывают, что для проведения подобных исследований болотных отложений подходит система антенн в 300 МГц. Предположительно, с системой антенн в 300 МГц возможно получать информативные сигналы в болотных отложениях, по меньшей мере, до глубины 4,5 м. Анализ данных показывает, что в разрезах скважин можно выделить 4 слоя торфа с разной степенью влажности, которые прослеживаются по всей исследуемой территории. Границы данных слоев считаются возможными поверхностями отражения радиолокационного сигнала. Так же на всей территории исследования возможно выделить границы слоев торфа с резкими изменениями степени разложения. Границы между слоями торфа с резко изменчивым содержанием пепла, которые бы прослеживались по всей исследуемой территории, выделить невозможно. Сделан вывод, что скорость распространения электромагнитных волн в слоях торфа следует определять с высокой точностью, используя метод общей средней точки, а так же, что доминирующее в предыдущих исследованиях мнение, что скорость распространения электромагнитных волн в торфе обуславливается только изменением степени влажности торфа, ошибочно. 